\title{
Evaluation of Vanadium Influence in AISi10MgMn Alloy with Increased Iron Level
}

Maria Zihalova, Dana Bolibruchova

Department of Technological Engineering, Faculty of Mechanical Engineering, University of Zilina, Univerzitna 8215/1, 01026 Zilina. Slovak Republic. E-mail: maria.zihalova@fstroj.uniza.sk, danka.bolibruchova@fstroj.uniza.sk

Final properties of castings made of aluminium alloys strongly depend on amount of impurities. Production of high quality parts thus requires strict control of impurity level or elimination of detrimental effects caused by presence of impurities. Such requirements are even more important in case of castings made of recycled materials. In Al-Si based alloys is very important awareness of the problems with the presence of iron as an impurity. Negative iron effect is expressive even in low amounts, and with higher level becomes more harmful. Elimination of its effects can be performed by several techniques, from which no one have general implementation. One of the possible ways is addition of so called iron correctors to the alloys. Influence of vanadium as iron corrector is still not precisely examined. In this article, influence of vanadium to AlSi10MgMn alloy with 1.0 wt. \% of iron is analysed by tensile and hardness testing together with microstructural evaluation.

Keywords: AlSi10MgMn alloy, Intermetallic phase, Correctors of iron, Vanadium

\section{Acknowledgements}

This work was created in the framework of the grant project $V E G A N^{\circ} 1 / 0363 / 13$. The authors acknowledge the grant agency for support.

\section{References}

[1] ZHANG, Y. et al. (2014). Efficient use of iron impurity in Al-Si alloys. In: Journal of Alloys and Compounds, Vol. 615, pp. 594 - 597.

[2] PASTIRCAK, R. (2014). Effect of Low Pressure Application during Solidification on Microstructure of Al-Si Alloys. In: Manufacturing Technology, Vol. 14, No. 3, pp. 397-400.

[3] JI, S. et al. (2013). Effect of iron on the microstructure and mechanical property of $\mathrm{Al}-\mathrm{Mg}-\mathrm{Si}-\mathrm{Mn}$ and $\mathrm{Al}-\mathrm{Mg}-\mathrm{Si}$ die cast alloys. In: Materials Science \& Engineering A, Vol. 564, pp. 130 - 139.

[4] SHABESTARI, S. G. (2004). The effect of iron and manganese on the formation of intermetallic compounds in aluminum-silicon alloys. In: Materials Science \& Engineering A, Vol. 383, pp. 289-298.

[5] GAO, J. W. et al. (2007). Effects of $\mathrm{Na}_{2} \mathrm{~B}_{4} \mathrm{O}_{7}$ on the elimination of iron from aluminium melt. In: Stripta Materialia, Vol. 57, pp. $289-298$.

[6] CAO, X., CAMPBELL, J. (2006). Morphology of $\beta-\mathrm{Al}_{5} \mathrm{FeSi}$ Phase in Al-Si Cast Alloys. In: Materials Transactions, Vol. 47, No. 5, pp. 1303 - 1312.

[7] PASTIRČÁK, R., KRIVOŠ, E. (2013). Effect of opening material granularity on the mould properties and the quaility of castings made by patternless process technology. In: Manufacturing Technology. Vol. 13, No. 1, pp. $92-97$.

[8] PETRÍK, J., SZARVASY, P., ŠPEŤUCH, V. (2004). Vlastnosti silumínu s obsahom železa, niklu a mangánu. In: Acta Metallurgica Slovaca, Vol. 10, No. 2, pp. 73 - 79.

[9] PETRÍK, J., HORVATH, M. (2011). The iron correctors in Al-Si alloys. In: Annals of Faculty Engineering Hunedoara - International journal of engineering, Vol. 9, No. 3, pp. 401 - 405.

[10]TAYLOR, J. A. (2012). Iron-containing intermetallic phases in Al-Si based casting alloys. In: Procedia Materials Science, Vol. 1, pp. 19 - 33.

[11]ASM INTERNATIONAL (1992) ASM Handbook. Volume 3. Alloy Phase Diagrams. 1st. ed. ASM International: USA, pp. 1741

[12]HURTALOVÁ, L. et al. (2014). Microstructure control of secondary A 231 cast alloy used in automotive industry. In: Manufacturing Technology. Vol. 14, No. 3, pp. 326 - 333.

[13] GRÍGEROVÁ, T., KOŘENÝ, R., LUKÁČ, I. (1988). Zlievárenstvo neželezných kovov. ALFA: Bratislava, pp. 424. (in Slovak) 